\title{
Lectotypification of Actinidia latifolia var. deliciosa (Actinidiaceae)
}

\section{Li Xin-wei, Shi Quan-fen, and Li Jian-qiang*}

Key Laboratory of Aquatic Botany and Watershed Ecology, Herbarium (HIB), Wuhan Botanical

Garden, Chinese Academy of Sciences, Wuhan 430074, People's Republic of China.

*Author for correspondence: lijq@rose.whiob.ac.cn

Aвstract. A lectotype is designated for Actinidia latifolia (Gardner \& Champ.) Merr. var. deliciosa A. Chev. (Actinidiaceae), selecting the second plate from the Chevalier protologue. Actinidia latifolia var. deliciosa is the basionym for the well-known kiwifruit A. deliciosa (A. Chev.) C. F. Liang \& A. R. Ferguson. Key words: Actinidia, Actinidiaceae.

Auguste J. B. Chevalier (1940) described Actinidia latifolia (Gardner \& Champ.) Merr. var. deliciosa A. Chev. from the plant cultivated in the Jardin des Plantes, Paris. Chevalier soon recognized that the variety belonged to A. chinensis Planch. and proposed the new combination in 1941 as A. chinensis var. deliciosa (A. Chev.) A. Chev. Liang (1975) described A. chinensis var. hispida C. F. Liang, which proved to be the same taxon as A. chinensis var. deliciosa (Liang \& Ferguson, 1984, 1986; Ferguson, 1990). Gui (1981) was the first to point out that the morphological distinction between A. chinensis var. deliciosa and the autonymic variety justified specific separation. Although Liang (1982) stressed that A. chinensis var. deliciosa should not be given specific status, Liang and Ferguson $(1984,1986)$ did raise it to the rank of species in the new combination A. deliciosa (A. Chev.) C. F. Liang \& A. R. Ferguson. From then on, it has been hotly debated whether the two taxa are two distinct species or not (Ferguson, 1990; Xiong, 1991; Webby et al., 1994; Hirsch et al., 2002; Huang et al., 2002; Chat et al., 2004; Jia et al., 2005; J. Q. Li et al., 2007; Z. Z. Li et al., 2007). However, the type has remained ambiguous until now.

The two taxa are very similar to each other. The main differences between Actinidia chinensis var. chinensis and A. chinensis var. deliciosa are that the former has young branchlets and petioles that are white pubescent to roughly tomentose, glabrous to glabrate when mature, and fruits that are densely tomentose, but soon glabrous. In variety deliciosa, the young branchlets and petioles are brownish strigose, with the hairs not easily lost, and the fruits are densely hispid, more or less hispid when mature (J. Q. Li et al., 2007). Actinidia chinensis var. deliciosa is mainly distributed in western mainland China, whereas $A$. chinensis var. chinensis is found further to the east (Liang, 1975; Ferguson, 1990; J. Q. Li et al., 2007). The plants are of great economic importance, because their fruits, well-known as kiwifruit, are popular all over the world. More than 120,000 ha. of orchard are planted with the two taxa, with an annual production exceeding 1.35 million tons of fresh fruit (Ferguson \& Huang, 2007).

The taxonomy of Actinidia chinensis var. chinensis and A. chinensis var. deliciosa needs further revision based on extensive population sampling across their entire geographic range, with careful observation of the variation of morphological characters and investigation of genetic variation using molecular markers. However, when A. latifolia var. deliciosa was published, no specimen was selected as a type (Chevalier, 1940). We suspected that perhaps Chevalier had preserved a specimen in the Muséum National d'Histoire Naturelle (P), since the plant was cultivated in the Jardin des Plantes in Paris. Dr. Joël Jérémie kindly helped in searching through the specimens at $\mathrm{P}$ identified as A. latifolia var. deliciosa, in particular for specimens annotated by Auguste Chevalier, but no type specimen was ever discovered. We therefore think that it is necessary to designate a type. There are two illustrations in the protologue of $A$. latifolia var. deliciosa (Chevalier, 1940). The first one shows the whole liana growing against a wall in the Jardin des Plantes. The second plate (Chevalier, 1940: 15, planche II; our Fig. 1) shows a fruiting branch alongside detached fruits (one bisected longitudinally). This plate is referenced by Chevalier at the end of his description (Chevalier, 1940: 14) and is easily recognizable as $A$. latifolia var. deliciosa (i.e., $A$. chinensis var. deliciosa). Plate 2 clearly displays the characters distinguishing A. latifolia var. deliciosa from A. latifolia, i.e., the orbicular leaf blade with a subcordate base and an almost rounded apex; the fruiting branch with one to two fruits per infructescence; and fruits that are ellipsoid or ovoid and hispid, with reflexed persistent sepals and long pedicels. In contrast, the infructescence of A. latifolia has many glabrous fruits when mature. According to Articles 9.2, 9.9, and 9.10 of the International Code of 


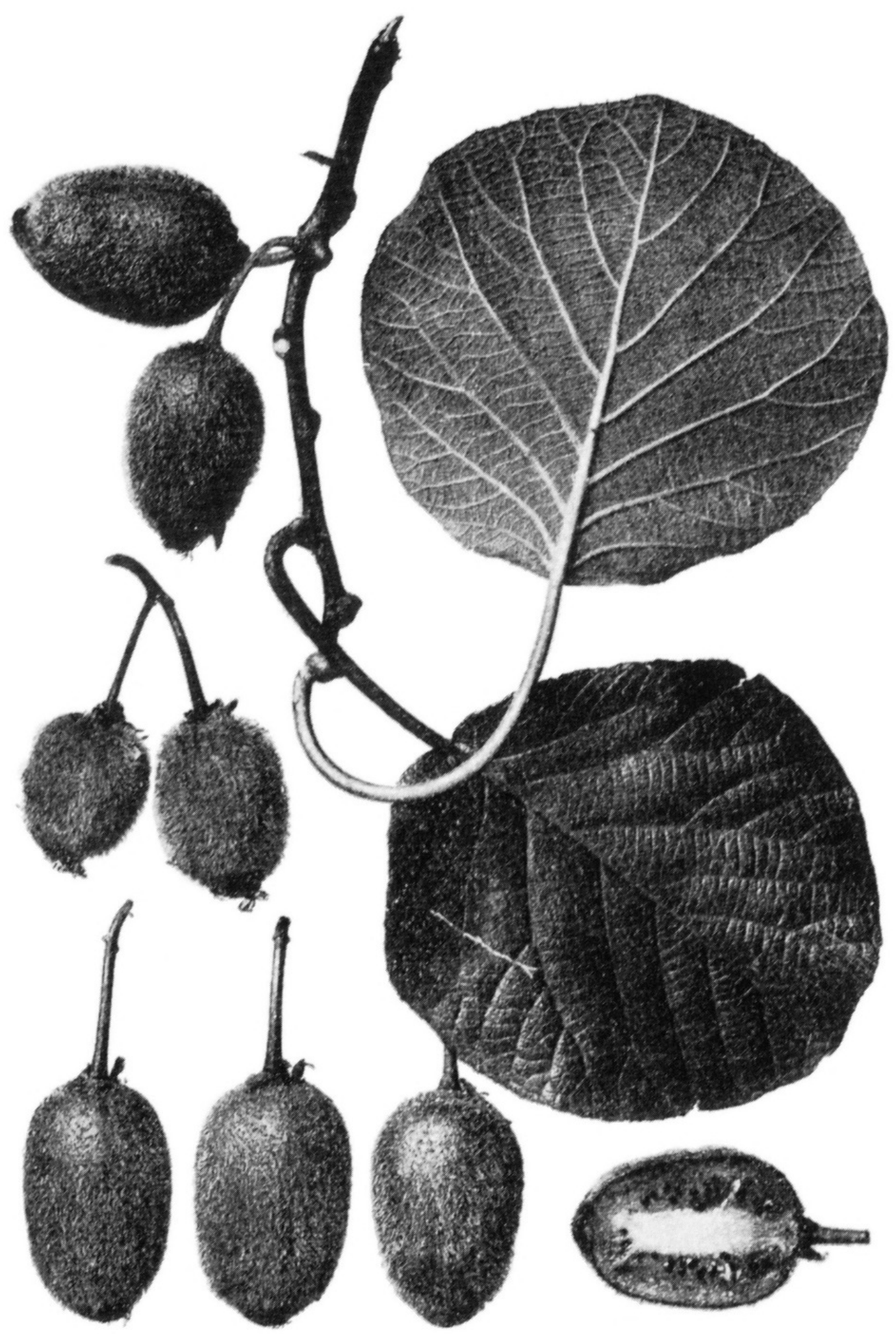

Figure 1. Lectotype of Actinidia latifolia (Gardner \& Champ.) Merr. var. deliciosa A. Chev. The original caption read "Fructification du même" (Chevalier, 1940: 15, pl. 2).

Botanical Nomenclature (McNeill et al., 2006), we here designate this second illustration as the lectotype of A. latifolia var. deliciosa.

Actinidia latifolia (Gardner \& Champ.) Merr. var. deliciosa A. Chev., Rev. Bot. Appl. Agric. Trop.
20: 12. 1940. TYPE: "Fructification du même," Planche II in Chevalier, 1940 (lectotype, designated here, Pl. 2 in Chevalier, 1940: 15). EPITYPE: China. Hubei: Wufeng, 2 Aug. 1959, R. H. Huang 1991 (epitype, HIB). Figure 1. 
Acknowledgments. We are grateful to Nicholas J. Turland (MO) for his helpful discussion with us and Joël Jérémie $(\mathrm{P})$ for his search and examination of the Actinidia specimens at the Muséum National d'Histoire Naturelle. This study was supported by grants from the Chinese Academy of Sciences (KSCX2-YWZ-409) and from Wuhan Botanical Garden, Chinese Academy of Sciences (O754521G04).

\section{Literature Cited}

Chat, J., B. Jáuregui, R. J. Petit \& S. Nadot. 2004. Reticulate evolution in kiwifruit (Actinidia, Actinidiaceae) identified by comparing their maternal and paternal phylogenies. Amer. J. Bot. 91: 736-747.

Chevalier, A. 1940. Sur des lianes fruitières intéressantes: Les Actinidia. Rev. Bot. Appl. Agric. Trop. 20: 10-15.

. 1941. Un Actinidia à fruits comestibles intéressant pour la Franch. (A. chinensis Planch. var. deliciosa Chev.). Rev. Bot. Appl. Agric. Trop. 21: 240-244.

Ferguson, A. R. 1990. Botanical nomenclature: Actinidia chinensis, Actinidia deliciosa, and Actinidia setosa. Pp. 36-57 in I. J. Warrington \& G. C. Weston (editors), Kiwifruit: Science and Management. Ray Richards Publishers and New Zealand Society for Horticultural Science, Auckland.

\& H. W. Huang. 2007. Genetic resources of kiwifruit: Domestication and breeding. Hort. Rev. 33: $1-121$.

Gui, Y. L. 1981. Comparative morphological observations of Actinidia chinensis Planch. var. chinensis and A. chinensis Planch. var. hispida C. F. Liang. Acta Phytotax. Sin. 19: 304-307.

Hirsch, A. M., A. Longeon \& M. Guyot. 2002. Fraxin and esculin: Two coumarins specific to Actinidia chinensis and A. deliciosa (kiwifruit). Biochem. Syst. Ecol. 30: $55-60$.
Huang, H. W., Z. Z. Li, J. Q. Li, T. L. Kubisiak \& D. R. Layne. 2002. Phylogenetic relationships in Actinidia as revealed by RAPD analysis. J. Amer. Soc. Hort. Sci. 127: 759-766.

Jia, B., L. W. Zhu, X. Yu, L. J. Lu \& Y. F. Wang. 2005. RAPD analysis on germplasm resources in genus Actinidia. J. Anhui Agric. Univ. 32: 381-384.

Li, J. Q., X. W. Li \& D. D. Soejarto. 2007. Actinidiaceae. Pp. 334-360 in Z. Y. Wu, P. H. Raven \& D. Y. Hong (editors), Flora of China, Vol. 12: Hippocastanaceae through Theaceae. Science Press, Beijing, and Missouri Botanical Garden Press, St. Louis.

Li, Z. Z., M. Kang, H. W. Huang, R. Testolin, Z. W. Jiang, J. Q. Li, Y. Wang \& G. Cipriani. 2007. Phylogenetic relationships in Actinidia as revealed by nuclear DNA genetic markers and cytoplasmic DNA sequence analysis. Acta Hort. 753: 45-58.

Liang, C. F. 1975. Classification of Actinidia chinensis Planch. Acta Phytotax. Sin. 13: 32-35.

- 1982. An addition to the infraspecific taxa of Actinidia chinensis Planch. Acta Phytotax. Sin. 20: 101-104.

\& A. R. Ferguson. 1984. Emendation of the Latin name of Actinidia chinensis Pl. var. hispida C. F. Liang. Guihaia 4: 181-182.

\& _ 1986. The botanical nomenclature of the kiwifruit and related taxa. New Zealand J. Bot. 24: 183-184.

McNeill, J., F. R. Barrie, H. M. Burdet, V. Demoulin, D. L. Hawksworth, K. Marhold, D. H. Nicolson, J. Prado, P. C. Silva, J. E. Skog, J. H. Wiersema \& N. J. Turland (editors). 2006. International Code of Botanical Nomenclature (Vienna Code). Regnum Veg. 146.

Webby, R. F., R. D. Wilson \& A. R. Ferguson. 1994. Leaf flavonoids of Actinidia. Biochem. Syst. Ecol. 22: 277-286.

Xiong, Z. T. 1991. Studies on the phylogenetic relationship between Actinidia chinensis and A. deliciosa using cladistic analysis. Guihaia 11: 36-39. 


\section{$2 \mathrm{BHL}$ Biodiversity Heritage Library}

Li, Xin-Wei and Shi, Quan-Fen. 2010. "Lectotypification of Actinidia latifolia var. deliciosa (Actinidiaceae)." Novon a journal of botanical nomenclature from the Missouri Botanical Garden 20, 57-59.

View This Item Online: https://www.biodiversitylibrary.org/item/123332

Permalink: https://www.biodiversitylibrary.org/partpdf/121981

\section{Holding Institution}

Missouri Botanical Garden, Peter H. Raven Library

\section{Sponsored by}

Missouri Botanical Garden

\section{Copyright \& Reuse}

Copyright Status: Permission to digitize granted by rights holder Rights: https://www.biodiversitylibrary.org/permissions

This document was created from content at the Biodiversity Heritage Library, the world's largest open access digital library for biodiversity literature and archives. Visit BHL at https://www.biodiversitylibrary.org. 